DOI: https://doi.org/10.24127/ajpm.v9i1.2591

\title{
MODUL GEOMETRI RUANG BERBASIS PROBLEM BASED LEARNING TERHADAP KREATIVITAS PEMECAHAN MASALAH
}

\author{
Rina Febriana ${ }^{1}$, Radhya Yusri², Hafizah Delyana ${ }^{3}$ \\ ${ }^{1,2,3}$ Pendidikan Matematika, STKIP PGRI Sumatera Barat, Padang, Indonesia \\ E-mail: $\quad$ rinafebriana0502@ gmail.com ${ }^{1)}$ \\ radhyayusri@gmail.com ${ }^{2)}$ \\ hafizahdelyana@gmail.com $^{3)}$
}

Received 06 January 2020; Received in revised form 30 January 2020; Accepted 28 March 2020

\begin{abstract}
Abstrak
Penelitian ini bertujuan untuk mengetahui kreativitas pemecahan masalah setelah menerapkan Modul Geometri Ruang berbasis Problem Based Learning. Jumlah sampel pada penelitian ini adalah 25 orang Mahasiswa Program Studi Pendidikan Matematika STKIP PGRI Sumatera Barat. Instrumen yang digunakan adalah tes dan angket. Tes yang digunakan berbentuk essay dan memuat indikator kemampuan pemecahan masalah. Angket yang digunakan pada penelitian ini merupakan angket tertutup yang terdiri dari 13 butir pertanyaan. Teknik análisis yang dilakukan adalah analisis kuantitatif untuk kemampuan pemecahan masalah mahasiswa dan deskriptif untuk melihat tingkat berpikir kreatif mahasiswa dalam menyelesaikan permasalahan. Hasil penelitian menunjukkan bahwa rata-rata kemampuan pemecahan masalah mahasiswa sudah baik dilihat dari rata-ratanya 78,6, serta mahasiswa memberikan respon yang positif terhadap pemecahan masalah. Sehingga, dapat disimpulkan bahwa penggunaan Modul Problem Based Learning mampu meningkatkan kemampuan pemecahan masalah mahasiswa dan mendukung kreativitas mahasiswa dalam menyelesaikan masalah.
\end{abstract}

Kata kunci: Geometri; kreativitas; pemecahan masalah; problem based learning.

\begin{abstract}
This study aims to determine the ability of students to solve problems after applying the Problem Based Learning Geometry Module. The number of samples in this study was 25 students of STKIP PGRI Mathematics Education Study Program in West Sumatra. The instruments used were tests and questionnaires. The test used is in the form of essays and contains indicators of problem solving ability. The questionnaire used in this study was a closed questionnaire consisting of 13 questions. The analysis technique used is quantitative analysis for students' problem solving skills and descriptive to see the level of creative thinking of students in solving problems. The results showed that generally there was a significant increase between the pretest and posttest scores, and students gave positive responses to creative problem solving. So, it can be concluded that the use of the Problem Based Learning Module was able to support student creativity in solving problems.
\end{abstract}

Keywords: Geometry; creativity; problem based learning; problem solving.

\section{PENDAHULUAN}

Kreativitas dapat melahirkan gagasan nyata, baik dalam karya baru maupun kombinasi dengan hal-hal yang sudah ada, yang semuanya itu relatif berbeda dengan apa yang telah ada sebelumnya. Kreativitas merupakan sebagai sarana untuk meningkatkan kreativitas individu, kelompok, dan organisasi (Althuizen \& Wierenga,
2014; Nadjafikhah, Yaftian, \& Bakhshalizadeh, 2012). Berpikir kreatif mendorong pengembangan keterampilan metakognitif (Hargrove \& Nietfeld, 2015). Untuk menghasilkan suatu cara atau sesuatu yang baru dalam memandang suatu masalah atau sesuatu, kreativitas dipandang sebagai suatu kemampuan mampun aktivitas individu. Pemecahan masalah secara kreatif 
DOI: https://doi.org/10.24127/ajpm.v9i1.2591

merupakan kunci dari pemecahan masalah yang berkualitas dan mencari solusi yang lebih untuk masalah keberlanjutan (Mitchell \& Walinga, 2017).

\begin{tabular}{llr}
\multicolumn{2}{c}{ Beberapa penelitian } & yang \\
berkaitan dengan modul berbasis & Problem Based Learning & $(P B L)$ \\
menunjukkan hasil yang positif
\end{tabular}
terhadap proses pembelajaran. Menurut Sumartini (2016) untuk meningkatkan kemampuan pemecahan masalah siswa, perlu didukung oleh metode pembelajaran yang tepat. Salah satu pembelajaran untuk meningkatkan kemampuan pemecahan masalah adalah pembelajaran berbasis masalah (Problem Based Learning). Hal ini juga ditegaskan oleh Sari (2014) yang menyatakan bahwa peningkatan kemampuan pemecahan masalah matematika siswa yang diajar dengan pendekatan Problem Based Learning lebih tinggi dari pada siswa yang diajar secara konvensional. Selanjutnya, Zubaidah (2016) menyatakan bahwa keterampilan memecahkan masalah memiliki peranan yang penting dalam kegiatan pembelajaran. Hal ini juga diperkuat berdasarkan hasil penelitian Monica, dkk (2019), yang menyimpulkan bahwa terdapat pengaruh model PBL terhadap kemampuan pemecahan masalah. Dari beberapa penelitian tersebut belum ada yang meneliti modul Geometri Ruang berbasis Problem Based Learning terhadap kreativitas pemecahan masalah.

Pada kenyataan mahasiswa masih kesulitan dalam menyelesaikan suatu permasalahan matematika. Kesulitan itu lebih disebabkan suatu pandangan yang mengatakan bahwa jawaban akhir dari permasalahan merupakan tujuan dari pembelajaran. Prosedur mahasiswa matematika dalam menyelesaikan permasalahan kurang, bahkan kurang diperhatikan oleh dosen karena terlalu berorientasi pada kebenaran jawaban akhir. Kemampuan mereka dalam memberikan alasan terhadap solusi juga masih rendah. Ketika beberapa mahasiswa matematika yang memperoleh jawaban akhir yang benar diminta menjelaskan proses penyelesaian masalah tersebut, ternyata tidak semuanya mampu menjelaskan dengan baik. Selain itu, perhatian dosen terhadap kreativitas mahasiswa dalam menyelesaikan permasalahan masih kurang. Kemampuan pemecahan masalah merupakan kemampuan yang harus dimiliki mahasiswa. Sehingga mampu menyiapkan mahasiswa yang memiliki kemampuan pemecahan masalah matematis

Untuk mendorong keterampilan berpikir kreatif mahasiswa dalam memecahkan masalah diperlukan suatu metode, teknik atau perangkat yaitu modul berbasis Problem Based Learning. Penggunaan modul dapat proses pembelajaran dapat membantu mahasiswa lebih aktif dalam belajar, karena mahasiswa akan berfikir dan menggunakan kemampuan untuk menemukan hasil akhir. Kemampuan mahasiswa dalam menyelesaikan permasalahan mengacu pada kemampuannya untuk mendapatkan banyak solusi dari permasalahan yang diberikan (Chairan, 2016). Dalam pemecahan masalah, kreativitas memiliki efek positif terhadap peningkatan pola pikir, karakter dan pemecahan masalah kreatif (Febriana, Haryono \& Yusri, 2017; Prabowo \& Sidi, 2010). Salah satu perangkat yang bermanfaat dan dapat mengembangkan kreativitas dan keterampilan berpikir kritis adalah perangkat pembelajaran berbasis masalah (Siswono, 2011). Problem Based Learning dapat 
dijadikan sebagai alat atau metode untuk pengembangan bakat peserta didik yang memungkinkan pendidik melihat serangkaian keterampilan dan kemampuan yang lebih lengkap diantara peserta didiknya (Kim, Choe \& Kaufman, 2019).

Langkah-langkah pemecahan masalah yang digunakan merujuk pada Polya yang terdiri dari 4 tahap, yaitu: memahami masalah, merencanakan penyelesaian masalah, menyelesaikan masalah sesuai rencana, dan melakukan pengecekan kembali terhadap semua langkah yang dikerjakan atau menafsirkan solusinya (Chairan, 2016).

Mengingat kreativitas mempunyai peran penting bagi mahasiswa dalam menyelesaikan permasalahan, maka solusi yang digunakan untuk menyelesaiakan permasalahan tersebut yang penggunaan modul berbasis Problem Based Learning dalam proses pembelajaran untuk mengetahui kreativitas kemampuan pemecahan masalah mahasiswa.

\section{METODE PENELITIAN}

Penelitian ini merupakan penelitian quasi eksperimen. Desain penelitian pada penelitian quasi eksperimen ini adalah the one group pretest-posttest design. Variabel dalam penelitian ini adalah : 1) variabel bebas penelitian ini yaitu penggunaan modul Berbasis Problem Based Learning, 2) variabel terikat penelitian ini yaitu kemampuan pemecahan masalah mahasiswa dan tingkat kreativitas pemecahan masalah mahasiswa.

Teknik pengambilan sampel menggunakan purporsive sampling. Sampel yang dipilih adalah satu kelas karena pertimbangan dari dosen yang mengampu mata kuliah dan berdasarkan hasil observasi awal yang dilihat dari kemampuan pemecahan masalah mahasiswa. Sampel pada penelitian ini adalah 25 orang mahasiswa dari Program Studi Pendidikan Matematika STKIP PGRI Sumatera Barat. Instrumen yang digunakan adalah tes dan angket. Tes digunakan untuk mengetahui peningkatan kemampuan pemecahan masalah mahasiswa sebelum dan setelah menggunakan modul. Tes berbentuk essay yang terdiri atas 5 buah soal yang memuat indikator kemampuan pemecahan masalah. Angket terdiri atas 10 butir pernyataan. Angket digunakan untuk mengetahui respon mahasiswa terhadap kreativitas memecahkan masalah yang memuat 3 indikator, yaitu: kefasihan, fleksibilitas, dan kebaruan. Teknik análisis yang dilakukan adalah analisis kuantitatif. Data dianalisis menggunakan Uji-t Sampel Berpasangan yang dikenal dengan istilah Uji Paired Sample TTest. Kriteria data untuk Uji-t Berpasangan adalah data untuk tiap pasang yang diuji dalam skala interval, berdistribusi normal, dan nilai variannya dapat sama ataupun tidak.

\section{HASIL DAN PEMBAHASAN}

Tes yang diberikan berjumlah 5 soal dan memuat indikator kemampuan pemecahan masalah. Kemampuan pemecahan masalah mahasiswa perlu ditingkatkan untuk melatih mahasiswa untukmampu berpikir secara mandiri dalam memecahkan masalah. Kemampuan pemecahan masalah mahasiswa dapat dilatih dengan modul berbasis Problem Based Learning. Modul tersebut diharapkan mampu mengembangkan potensi berpikir mahasiswa. Berikut adalah rata-rata hasil nilai pre-test dan post-test kemampuan pemecahan masalah mahasiswa. 
DOI: https://doi.org/10.24127/ajpm.v9i1.2591

Tabel 1. Hasil tes kemampuan pemecahan masalah mahasiswa

\begin{tabular}{lcccc}
\hline \multicolumn{1}{c}{ Nilai } & $\begin{array}{c}\text { Rata } \\
\text {-rata }\end{array}$ & $\begin{array}{c}\text { Nilai } \\
\text { Max }\end{array}$ & $\begin{array}{c}\text { Nilai } \\
\text { Min }\end{array}$ & $\begin{array}{c}\text { Std } \\
\text { Dev. }\end{array}$ \\
\hline $\begin{array}{l}\text { Pre-test } \\
\begin{array}{l}\text { Post- } \\
\text { test }\end{array}\end{array}$ & 49,8 & 65 & 40 & 6,63 \\
\hline
\end{tabular}

Tabel 1 menunjukkan rata-rata nilai tes yang diperoleh bahwa kemampuan memecahkan masalah matematika mahasiswa lebih baik setelah menerapkan pembelajaran $P B L$. Hasil simpangan baku menunjukkan bahwa rata-rata nilai pretest dan posttest mahasiswa tidak terlalu jauh dari nilai rata-rata kelas. Pada hasil posttest diketahui bahwa masih terdapat 10 orang mahasiswa yang nilainya masih di bawah rata-rata.

Data pada penelitian ini diolah menggunakan SPSS 16. Langkah pertama dalam analisis data adalah melakukan uji normalitas pada data pretest dan postes. Hal ini bertujuan untuk melihat apakah data pemahaman konsep matematika siswa berdistribusi normal atau tidak. Uji yang digunakan adalah Shapiro Wilk karena sampel berukuran kecil. Hasil uji normalitas kedua data tersebut disajikan pada Tabel 2.

Tabel 2. Hasil uji normalitas.

\begin{tabular}{lccc}
\hline \multirow{2}{*}{ Nilai } & \multicolumn{3}{c}{ Shapiro Wilk } \\
\cline { 2 - 4 } & Statistic & df & Sig. \\
\hline Pretest & 0,932 & 25 & 0,096 \\
Posttest & 0,923 & 25 & 0,061 \\
\hline
\end{tabular}

Berdasarkan output analisis data pada SPSS diketahui bahwa nilai sig. pada pretest 0,096 dan posttest 0,061. Hasil Sig. kedua kelompok besar dari 0,05, maka dapat disimpulkan bahwa data pretest dan posttest berdistribusi normal.

Selanjutnya, dilakukan pengujian homogenitas dengan output seperti pada Tabel 3.

Tabel 3. Hasil uji homogenitas.

\begin{tabular}{cccc}
\hline $\begin{array}{c}\text { Levene } \\
\text { Statistic }\end{array}$ & $\boldsymbol{d f 1}$ & $\boldsymbol{d f 2}$ & Sig. \\
\hline 1,351 & 1 & 48 & 0,251 \\
\hline
\end{tabular}

Setelah data berdistribusi normal dan homogen, maka dilakukan uji-t. Hasil uji-t berpasangan disajikan pada Tabel 4.

Tabel 4. Hasil pengujian hipotesis.

\begin{tabular}{ccc}
\hline$t$ & $d f$ & Sig. (2-tailed) \\
\hline 13,67 & 46 & 0,000 \\
\hline
\end{tabular}

Berdasarkan data pada Tabel 3 diketahui bahwa nilai signifikansi 0,251 jauh melebihi 0,05 , dengan demikian kedua data tersebut homogen. Selanjutnya untuk melihat pengaruh PBL terhadap keamampuan pemecahan masalah, dilakukan uji t (Tabel 4) diperoleh nilai $t_{\text {hitung }}=13,67$ dan $t_{\text {table }}=2,064$. Karena $t_{\text {hitung }}>t_{\text {tabel }}$ dan nilai Sig. $<0,05$ maka $\mathrm{H}_{0}$ ditolak. Sehingga dapat disimpulkan bahwa terdapat pengaruh modul geometri ruang berbasis $P B L$ terhadap kemampuan pemecahan masalah siswa.

Berdasarkan hasil jawaban mahasiswa diketahui bahwa kemampuan pemecahan mahasiswa masih kurang dalam hal memahami masalah, merencanakan pemecahan masalah, melaksanakan rencana dan memeriksa kembali prosedur dan hasil jawaban sehingga siswa kesulitan dalam memecahkan suatu permasalahan terutama dalam bentuk soal cerita. Soal tes yang diberikan memuat indikator 
kemampuan pemecahan masalah, yaitu; (1)memahami masalah, (2) membuat rencana untuk menyelesaikan masalah, (3) melaksanakan penyelesaian soal, dan (4) memeriksa ulang jawaban yang diperoleh.

Hal ini juga diperkuat oleh Silver (1997) yang mengatakan bahwa menggunakan masalah terbuka dapat memberikan siswa banyak pengalaman dalam menafsirkan masalah. Sehingga, mahasiswa perlu membiasakan diri memecahkan masalah dengan mengikuti langkah-langkah pemecahan masalah karena dapat mengembangkan kemampuan metakognisi siswa, sehingga siswa dapat memupuk sifat teliti, kritis, dan terampil dalam mengambil keputusan (Nugrahaningsih \& Theresia, 2011)

Berdasarkan hasil tes kemampuan pemecahan masalah mahasiswa diketahui bahwa mahasiswa yang kemampuan pemecahan masalahnya pada indikator memahami masalah berada di kategori tinggi dengan ratarata persentase mahasiswa yang mampu memahami masalah dengan baik adalah 94,4\% dimana hampir semua siswa di kelas sampel mampu memahami masalah dengan baik. Sebaliknya persentase kemampuan pemecahan masalah mahasiswa pada indikator memeriksa ulang jawaban yang diperoleh rendah yaitu $56 \%$ dimana hanya sebagian siswa yang memeriksa kembali jawabannya.

Berdasarkan pelaksanaan pembelajaran di kelas diketahui bahwa $P B L$ tidak dirancang untuk membantu guru menjelaskan konsep secara detail kepada mahasiswa, namun PBL dikembangkan untuk membantu mahasiswa dalam mengembangkan kemampuan berpikir, pemecahan masalah, dan keterampilan intelelektual, belajar sebagai peran orang dewasa melalui pelibatan mereka dalam pengalaman nyata atau simulasi. Hal ini sejalan dengan pendapat Putra yang menyatakan bahwa manfaat dari pembelajaran berbasis masalah PBL adalah siswa dapat mengembangkan kemampuan berpikir, pemecahan masalah, serta kemampuan intelektual (Putra, \& Rizema, 2012).

Berikut salah satu contoh soal pemecahan masalah yang diberikan kepada mahasiswa setelah menerapkan penggunaan modul Geometri Ruang berbasis $P B L$.

Diketahui limas beraturan T.ABCD dengan rusuk alas $2 \mathrm{~cm}$ dan rusuk tegak $\sqrt{3}$.

Tentukan jarak dan nilai tangen sudut antara rusuk TD dan bidang alas ABCD!

Jawaban mahasiswa yang memiliki kemampuan pemecahan masalah berada pada kategori baik dimana mahasiswa tersebut sudah mampu memahami masalah, membuat rencana penyelesaian soal, dan memeriksa ulang jawaban. Mahasiswa sudah menguasai konsep jarak pada materi geometri ruang

Namun mahasiswa yang memiliki kemampuan pemecahan masalah rendah belum mampu menyelesaikan masalah dan belum mampu memeriksa kembali jawabannya. Data hasil angket respon mahasiswa dalam kreativitas memecahkan masalah disimpulkan dalam Tabel 5.

Tabel 5. Hasil Angket Respon.

\begin{tabular}{|c|c|c|}
\hline No & Pernyataan & Respon Mahasiswa \\
\hline 1 & $\begin{array}{l}\text { Dalam mengikuti } \\
\text { perkuliahan, saya } \\
\text { bebas } \\
\text { mengeluarkan } \\
\text { pendapat }\end{array}$ & $\begin{array}{l}\text { Dalam mengikuti } \\
\text { proses pembelajaran } \\
\text { mahasiswa bebas } \\
\text { mengeluarkan } \\
\text { pendapat }\end{array}$ \\
\hline 2 & $\begin{array}{l}\text { Dalam } \\
\text { mengerjakan } \\
\text { soal, saya bebas }\end{array}$ & $\begin{array}{l}\text { Dalam } \\
\text { menyelesaikan } \\
\text { permasalahan }\end{array}$ \\
\hline
\end{tabular}


DOI: https://doi.org/10.24127/ajpm.v9i1.2591

\begin{tabular}{|c|c|c|}
\hline No & Pernyataan & Respon Mahasiswa \\
\hline & $\begin{array}{l}\text { menggunakan } \\
\text { cara yang saya } \\
\text { senangi }\end{array}$ & $\begin{array}{l}\text { mahasiswa bebas } \\
\text { menggunakan cara } \\
\text { yang mereka } \\
\text { mengerti tetapi bagi } \\
\text { siswa yang } \\
\text { berkemampuan } \\
\text { rendah mebuat } \\
\text { bingung karena } \\
\text { alternatif } \\
\text { penyelesaiannya } \\
\text { berbeda dengan yang } \\
\text { dibuatnya. }\end{array}$ \\
\hline 3 & $\begin{array}{l}\text { Saya senang } \\
\text { sekali mengikuti } \\
\text { perkuliahan } \\
\text { dengan suasana } \\
\text { yang tidak kaku }\end{array}$ & $\begin{array}{l}\text { Saya lebih senagn } \\
\text { dengan proses } \\
\text { pembelajaran yang } \\
\text { seperti } \\
\text { mahasisswanya yang } \\
\text { dituntut untuk aktif }\end{array}$ \\
\hline 4 & $\begin{array}{l}\text { Saya senang jika } \\
\text { dosen tidak } \\
\text { memberikan } \\
\text { pekerjaan rumah }\end{array}$ & $\begin{array}{lr}\text { Saya kurang } & \text { setuju, } \\
\text { karena saya lebih } \\
\text { suka kalau dosen } \\
\text { memberikan tugas } \\
\text { untuk mengulang } \\
\text { pelajaran } \\
\text { dirumah }\end{array}$ \\
\hline 5 & $\begin{array}{l}\text { Saya selalu } \\
\text { membuat rencana } \\
\text { penyelesaian } \\
\text { dalam } \\
\text { mengerjakan soal } \\
\text { yang diberikan } \\
\text { dosen dan } \\
\text { menjalankan } \\
\text { rencana tersebut }\end{array}$ & $\begin{array}{ll}\text { Saya setuju agar } \\
\text { proses } & \\
\text { menyelesaikan } & \\
\text { masalah } & \text { lebih } \\
\text { terstruktur } & \end{array}$ \\
\hline 6 & $\begin{array}{l}\text { Setelah } \\
\text { menemukan } \\
\text { jawaban, saya } \\
\text { mengoreksi } \\
\text { kembali langkah- } \\
\text { langkah yang } \\
\text { telah saya } \\
\text { lakukan }\end{array}$ & $\begin{array}{l}\text { Setuju, karena proses } \\
\text { ini mencek kembali } \\
\text { jawaban yang sudah } \\
\text { ditulis.tetapi dalam } \\
\text { hal ini banyak } \\
\text { mahasiswa yang } \\
\text { belum } \\
\text { melaksanakannya }\end{array}$ \\
\hline 7 & $\begin{array}{l}\text { Setelah } \\
\text { menyelesaikan } \\
\text { satu soal, saya } \\
\text { tertantang untuk } \\
\text { menyelesaikan } \\
\text { soal berikutnya }\end{array}$ & $\begin{array}{l}\text { Setuju, karena } \\
\text { tertantang untuk } \\
\text { melihat } \\
\text { berikutnya, tetapi } \\
\text { apabila tidak bisa } \\
\text { mengerjakan } \\
\text { mahasiswa yang } \\
\text { berkemampuan } \\
\text { rendah enggan untuk } \\
\text { melanjutkannya }\end{array}$ \\
\hline 8 & $\begin{array}{l}\text { Saya selalu ingin } \\
\text { tahu cara yang } \\
\text { lain, selain cara }\end{array}$ & $\begin{array}{l}\text { Setuju, karena ini } \\
\text { menuntut mahasiswa } \\
\text { untuk }\end{array}$ \\
\hline
\end{tabular}

\begin{tabular}{|c|c|c|}
\hline No & Pernyataan & Respon Mahasiswa \\
\hline 9 & $\begin{array}{l}\text { Dalam } \\
\text { pembelajaran ini } \\
\text { saya dilatih untuk } \\
\text { menggunakan } \\
\text { banyak gagasan }\end{array}$ & $\begin{array}{l}\text { alternative } \\
\text { penyelesaian dengan } \\
\text { cara yang berbeda } \\
\text { setuju }\end{array}$ \\
\hline 10 & $\begin{array}{l}\text { Setelah } \\
\text { mengerjakan } \\
\text { soal, saya akan } \\
\text { mengerjakan soal } \\
\text { itu lagi } \\
\text { menggunakan } \\
\text { cara lain }\end{array}$ & $\begin{array}{l}\text { Setuju, untuk melihat } \\
\text { mengecek jawaban } \\
\text { benar atau salahmya } \\
\text { dengan } \\
\text { menggunakan } \\
\text { alternative } \\
\text { penyelesaian yang } \\
\text { lain }\end{array}$ \\
\hline 11 & $\begin{array}{lr}\text { Saya senang } \\
\text { mengerjakan soal } \\
\text { dengan banyak } \\
\text { cara setelah } \\
\text { mengikuti cara } \\
\text { belajar ini }\end{array}$ & $\begin{array}{l}\text { Setuju, hal ini } \\
\text { berguna } \\
\text { melihat kemampuan } \\
\text { mahasiswa }\end{array}$ \\
\hline 12 & $\begin{array}{l}\text { Saya senang } \\
\text { mendiskusikan } \\
\text { cara lain dengan } \\
\text { teman-teman } \\
\text { sehingga saya } \\
\text { punya banyak } \\
\text { cara penyelesaian }\end{array}$ & $\begin{array}{lr}\text { Setuju, } & \text { karena } \\
\text { membuat interaksi } \\
\text { aktif antar sesama } \\
\text { mahasiswa }\end{array}$ \\
\hline 13 & $\begin{array}{l}\text { Karena saya } \\
\text { harus } \\
\text { mengerjakan } \\
\text { dengan banyak } \\
\text { cara, maka saya } \\
\text { memberi } \\
\text { perhatian lebih } \\
\text { pada soal itu }\end{array}$ & $\begin{array}{l}\text { Tidak setuju, karena } \\
\text { bukan memberikan } \\
\text { perhatian lebih kalau } \\
\text { untuk latihan tidak } \\
\text { masalah dengan } \\
\text { banyak solusi. }\end{array}$ \\
\hline
\end{tabular}

Berdasarkan hasil angket yang disebarkan kepada mahasiswa pada akhir pertemuan pembelajaran di kelas dieproleh beberapa faktor pendukung penelitian ini yang membantu dalam meningkatkan kreatifitas pemecahan masalah mahasiswa antara lain: 1) pada saat proses perkuliahan mahasiswa bebas mengeluarkan pendapat, sehingga proses pempelajaran tidak kaku (student centered Learning). 2) proses pembelajaran lebih terstruktur sehingga memudahkan mahasiswa dalam 
DOI: https://doi.org/10.24127/ajpm.v9i1.2591

menyelesaikan masalah. dalam menyelesaikan 3) proses masalah mempunyai banyak alternative penyelesaian

Berdasarkan uraian hasil tes hasil pemecahan masalah dan angket kreativitas pemecahan masalah diketahui bahwa secara umum kemampuan pemecahan masalah mahasiswa sudah baik dan mahasiswa memberikan respon yang positif terhadap kreativitas pemecahan masalah. Hal ini sejalan dengan Hamidah \& Suherman (2016); Monica, dkk. (2019); Sari (2014); yang menyatakan bahwa berpikir kreatif sangat diperlukan dalam pemecahan masalah matematika, sehingga untuk meningkatkan kemampuan berpikir kreatif tersebut, maka pendidik perlu menganalisis kemampuan mahasiswa dalam pemecahan masalah.

\section{KESIMPULAN DAN SARAN}

Berdasarkan hasil analisis data dan pembahasan dapat disimpulkan bahwa penggunaan Model Geometri Ruang Berbasis Problem Based Learning efektif untuk mendukung kemampuan pemecahan masalah mahasiswa dan menimbulkan respon yang positif dari mahasiswa terkait kreativitas pemecahan masalah.

Penggunaan Modul Berbasis Problem Based Learning sebaiknya dipertimbangkan sebagai alternatif model pembelajaran untuk mengembangkan kemampuan pemecahan masalah mahasiswa. Penerapan model ini dapat dilakukan mulai dari tingkat sekolah menengah, harapannya akan membiasakan anak untuk bersikap kreatif dalam memecahkan masalah.

\section{DAFTAR PUSTAKA}

Althuizen, N., \& Wierenga, B. (2014). Supporting creative problem solving with a case-based reasoning system. Journal of Management Information Systems, 31(1), 309-340.

Febriana, R., Haryono, Y., \& Yusri, R. (2017). Effectiveness of Discovery Learning-Based Transformation Geometry Module. In Journal of Physics: Conference Series, 895(1), (p.012003). IOP Publishing.

Hamidah, K., \& Suherman, S. (2016). Proses Berpikir Matematis Siswa dalam Menyelesaikan Masalah Matematika ditinjau dari Tipe Kepribadian Keirsey. Al-Jabar: Jurnal Pendidikan Matematika, 7(2), 231-248.

Hargrove, R. A., \& Nietfeld, J. L. (2015). The impact of metacognitive instruction on creative problem solving. The Journal of Experimental Education, 83(3), 291-318.

Kim, S., Choe, I., \& Kaufman, J. C. (2019). The development and evaluation of the effect of creative problem-solving program on young children's creativity and character. Thinking Skills and Creativity, 33:100590.

Monica, H., Kesumawati, N., \& Septiati, E. (2019). Pengaruh Model Problem Based Learning Terhadap Kemampuan Pemecahan Masalah Matematis dan Keyakinan Matematis Siswa. MaPan: Jurnal Matematika dan Pembelajaran, 7(1), 155-166.

Mitchell, I. K., \& Walinga, J. (2017). The creative imperative: The role of creativity, creative problem solving and insight as key drivers for sustainability. Journal of 
DOI: https://doi.org/10.24127/ajpm.v9i1.2591

Cleaner Production, 140, 18721884.

Nadjafikhah, M., Yaftian, N., \& Bakhshalizadeh, S. (2012). Mathematical creativity: some definitions and characteristics. Procedia-Social and Behavioral Sciences, 31, 285-291.

Prabowo, A., \& Sidi, P. (2010). Memahat Karakter Melalui Pembelajaran Matematika. In Proceeding of The 4th International Conference on Teacher Education: Join Conference UPI \& UPSI Bandung (pp. 165-177).

Sari, S. (2014) Pengaruh Pendekatan Pembelajaran Berbasis Masalah Terhadap Kemampuan Pemecahan Masalah Matematika Siswa Kelas VIII SMP Negeri 1 Padang Tahun Pelajaran 2013/2014, Jurnal Penelitian Pendidikan Matematika, 3(2).

Silver, E. A. (1997). Fostering Creativity through Instruction Rich in Mathematical Problem Solving and Thinking in Problem Posing. ZDM, 29(3), 75-80.

Zubaidah, S. (2016). Keterampilan abad ke-21: Keterampilan yang diajarkan Melalui Pembelajaran. Seminar Nasional Pendidikan dengan Tema "isu-isu strategis pembelajaran MIPA Abad 21. Kalimantan Barat: STKIP Persada Khatulistiwa Sintang. 